Article

\title{
Can Environmental Laws Fulfill Their Promise? Stories from Canada
}

\author{
Nigel Bankes ${ }^{1,2, *}$, Sharon Mascher ${ }^{1,3}$ and Martin Olszynski ${ }^{1}$ \\ 1 Faculty of Law, University of Calgary, Calgary, AB T2N 1N4, Canada; \\ E-Mails: smascher@ucalgary.ca (S.M.); molszyns@ucalgary.ca (M.O.) \\ 2 JG Jebsen Centre, University of Tromsø, Tromsø N-9019, Norway \\ 3 Faculty of Law, University of Western Australia, Perth WA 6009, Australia \\ * Author to whom correspondence should be addressed; E-Mail: ndbankes@ucalgary.ca; \\ Tel.: +1-403-220-7252; Fax: +1-403-282-8325.
}

Received: 21 April 2014; in revised form: 12 July 2014 / Accepted: 14 August 2014 /

Published: 5 September 2014

\begin{abstract}
Canadian environmental law has changed dramatically over the last 50 years, responding to some of the flaws and weaknesses identified by commentators seeking to explain the continuing trend in environmental degradation. The aim of this article is to tell the story of three pieces of Canadian environmental legislation, the Alberta Land Stewardship Act, the federal Species at Risk Act, and Alberta's Environmental Protection and Enhancement Act, with a view to exploring whether the environmental ambition underlying these pieces of legislation is being realized. Our overall conclusion is that there is a significant gap between the ambition of these three pieces of environmental legislation and their actual implementation but this gap arises from design choices made by the legislature and the executive, rather than something inherent in the law itself.
\end{abstract}

Keywords: environmental law; cumulative effects management; endangered species; environmental appeal boards

\section{Introduction}

The call for papers for this special issue asked to what extent the law, as an integral constituent of environmental law, may be responsible for the latter's failure to prevent environmental degradation [1,2]. In other words, is there something inherent about the law, that "particular family of human social 
arrangements, consisting of public and officially sanctioned norms defining both acceptable and unacceptable modes of individual and group behavior" [3], or about the subject (the environment) that makes it particularly problematic to enact and enforce a set of norms that will prevent environmental degradation.

This is clearly a very large topic that is far beyond the compass of any particular contribution to this volume. Accordingly, we have set ourselves a much narrower objective in this contribution. We begin with the idea that the face of environmental law in North America generally and Canada in particular has changed dramatically over the last 50 years. Fifty years ago environmental law (if it could be called that) was primarily the domain of the common law (i.e., actions in nuisance, trespass, negligence), where changes to doctrine "are so gradual that their significance is at first obscured" [4]. The inability of common law causes of action to keep up with growing public expectations drove the creation of the modern environmental state in the early 1970s [5]. In the U.S., what is now referred to as the "environmental decade" [6] saw the passage of all of that country's major environmental laws, including the National Environmental Policy Act [7], the Clean Air Act [8], and the Clean Water Act [9]. In Canada, the 1969 Throne Speech foreshadowed the passage of five new environmental statutes, including a Clean Water Act, Clean Air Act, Environmental Contaminants Act and Ocean Dumping Control Act (most of these eventually consolidated in the Canadian Environmental Protection Act [10]). What is now known as Environment Canada was created in 1971, and in 1977 the federal Fisheries Act was transformed into a relatively powerful environmental statute with the introduction of the habitat protection and pollution prevention provisions [11].

However, the continuing trend of environmental degradation suggested that this was not enough. Both scholars and practitioners began to identify numerous flaws and weaknesses in these new environmental regimes $[5,6,12]$. In Canada, these included excessively discretionary executive powers [13], sectoral as opposed to ecosystem approaches [14], the failure to adopt precautionary approaches [14] (pp. 64-65), lack of enforcement [13] (p. 234), limited (or non-existent) opportunities for public participation [5] (pp. 234-238) and the preoccupation of many rules with major harms to the neglect of cumulative impacts [15].

The federal and provincial governments in Canada have responded to at least some of these criticisms and we discuss three examples here. The first example is the Alberta Land Stewardship Act $(A L S A)$ [16]. This ambitious legislation was designed to establish a framework for regional planning as a means of addressing the problem of cumulative impacts by engaging in planning at a landscape level and establishing thresholds designed to protect ecological health and integrity. The second example is the federal Species At Risk Act (SARA) [17], which is Canada's endangered species statute. This equally ambitious statute is designed to protect Canada's biological diversity through a series of action-forcing provisions intended to protect species and their habitats. The third statute is Alberta's Environmental Protection and Enhancement Act (EPEA) [18] which was designed to bring together a number of sector specific statutes (e.g., air and water pollution statutes) under a single umbrella and is based on the recognition that "the protection of the environment is essential to the integrity of ecosystems and human health and to the well-being of society". One of the procedural innovations of this statute was the creation of an Environmental Appeals Board to provide an opportunity for closer examination of more important and contentious environmental approvals. 
Our aim is to see if there is still a gap between the ambition of these statutes and their actual implementation and, if so, to examine the reasons for that gap. We have chosen to examine these three statutes for several reasons. Both $A L S A$ and $S A R A$ are relatively recent statutes and therefore speak to the law's potential for change and improvement. All three regimes, but perhaps especially $A L S A$, were heralded when introduced as bold and innovative statutes that would drive positive environmental outcomes. We chose the EPEA and the EAB that it created to reflect on the role that process and institutions play in determining the effectiveness of environmental regimes.

Our overall conclusion is that there remains a significant gap between ambition and implementation. The reasons for this are no doubt complex but our more specific conclusions for each of the three regimes are as follows. Although still early in its implementation, $A L S A$ 's ambition is dependent on the executive's exercise of excessively discretionary powers. SARA's goals, on the other hand, have been thwarted not by excessively discretionary powers but rather by the government's refusal to adhere to the applicable statutory rules established by the statute for the recovery of species. Furthermore, the goals of the environmental appeal process in EPEA have been limited by narrow standing rules that have failed to keep up with developments in the general law. A common theme for all three regimes is the important role that the executive plays in explaining the implementation gap in environmental statutes. The problem in implementation may not be so much a problem with the law as it is a problem of the absence of political will to achieve the lofty goals of these important statutes. Our discussion also shows that while the courts can play a facilitative role in helping environmental statutes fulfill their "promise" [19], it will be much more difficult for them to play a constructive role in the face of broad discretionary powers (as is the case under $A L S A$ ) and statutory standing tests which insulate statutory regimes from broader developments in the common law (as under $E P E A$ ).

\section{The Alberta Land Stewardship Act}

$A L S A$ has the potential to be one of the most significant pieces of environmental legislation adopted within Alberta in the last couple of decades [20]. Promoted by the Government of Alberta as "the most comprehensive land-use policy in Canada and, indeed, in North America" [21], ALSA provides for landscape level land-use planning as a means to integrate decision-making and respond to the cumulative effects of development activity. In so doing, $A L S A$ recognizes that there are limits to the trade-offs a functioning ecosystem can be asked to make to reap economic benefits. One of the goals of $A L S A$, therefore, is to provide a means to plan for the needs of current and future generations and to enable sustainable development, by taking account of and responding to the cumulative effects of human endeavor [16] (Sections 1(2)(b),(d)). ALSA's environmental goals are laudable in any jurisdiction. In Alberta, where the economy is driven in large part by oil, gas, and oil sands production and the landscape is also significantly impacted by activities such as agriculture and commercial forestry, the challenges are evident.

If $A L S A$ successfully achieves its environmental goals, the legislation will serve as an example of a pro-active, ecosystem based environmental law focused on the management of cumulative impacts. However, many of the weaknesses identified in the environmental law literature referred to in the introduction remain embedded in $A L S A$ - most notably excessively discretionary executive powers - with the potential to undermine the implementation of this innovative legislation. Whether 
this weakness will result in a gap between $A L S A$ 's ambition and its ultimate implementation remains an outstanding question. However, it is possible to begin to answer this question by considering the experience with its implementation so far.

\subsection{Brief Overview of the Policy Background}

Following three years of stakeholder and public consultation, in 2008 the Government of Alberta committed to a new land use policy-the Land-use Framework [22]. A central theme in the Framework is the need to move from project-by-project approval processes to more formalized regional-level planning. To this end, the Framework states that the Government of Alberta will develop land-use plans on a specified timetable for seven identified regions, defined by the major watersheds in the province [22] (pp. 19,24), to direct regional decision-making. Accordingly, the Framework provides that each regional plan will define economic, environmental and social outcomes specific to the region and establish a broad plan for both private and public lands and natural resource use within the region [22] (p. 26). A key strategy in the Framework is a commitment to the use of cumulative effects management at the regional level, subject to the caveat that the emerging practice of cumulative effects management is an "art not a science" and should be used "pragmatically not dogmatically" [22] (p. 31). In keeping with this commitment, the Framework provides that limits will be established for the cumulative effects that economic development has on the air, land, water and biodiversity within the region.

\subsection{ALSA as Discretionary Legislation}

ALSA translates the Framework's foundational strategies into law. However, the legislative translation is steeped in unconstrained discretion. For example, the creation of both land-use regions and regional land-use plans is completely discretionary and the legislation does not incorporate the timelines included in the Framework [16] (Sections 3(1),4(1)). When a regional plan is created, ALSA leaves it to the discretion of Cabinet to set the terms of reference, to describe the required level of public and stakeholder consultation, and to prescribe the consideration to be accorded to economic, environmental and social issues [16] (Sections 51(a)-(d) and (g)-(h)). Additionally, while an approved plan is binding on the Crown, local government bodies, decision-makers and all other persons [16] (Section 115(1)), discretionary powers are available to exempt decision-makers [16] (Section 66) or grant variances to private interest holders [16] (Section 15.1(2)). Action in the courts to enforce non-compliance with $A L S A$ or a regional plan is reserved to the stewardship commissioner [16] (Sections 15(3),(5) and 18(1)), with public complaints left to a discretionary investigation and reporting process [16] (Section 62).

Perhaps most notably, ALSA leaves a regional plan's content largely to Cabinet discretion-requiring only that the plan describe the vision for the planning region and state one or more objectives [16] (Sections 8(1) and 13(1)). Significantly, elements essential to a cumulative effects management approach — such as thresholds, indicators and details relating to the monitoring and assessment of these thresholds, indicators and policies - are all left to the discretion of the Cabinet [16] (Section 8(2)). Also discretionary is inclusion of actions or measures to be taken if adverse trends or effects eventuate, thresholds are exceeded, or objectives or policies are not being 
maintained [16] (Section 15(2)(d)-(f)). Ultimately, a regional plan "may" contain provisions that the Cabinet considers necessary or appropriate to advance or implement the purposes of the Act [16] (Section 9(1)). As a result, the implementation of a cumulative effects management approach within any given regional plan is dependent on the exercise of executive discretion. With limited exceptions for a "person who is directly or adversely affected by a regional plan to request a review [16] (Section 19.2), no opportunity exists for interested parties to compel the exercise of this discretion to ensure $A L S A$ 's environmental aspirations will be attained.

\subsection{Implementation of ALSA}

The question then is whether the unconstrained discretionary powers of the legislation create an implementation gap between $A L S A$ 's ambition and the resulting plans. So far, from a process perspective, it is possible to suggest that the "fears associated with such broad discretionary authority appear to be overstated" [23]. Although well behind the timelines contemplated in the Framework, the regional planning process is underway in the two regions identified as first priorities. The plan for the first of these priority areas, the Lower Athabasca Regional Plan ("LARP”), took effect on September 1 2012 [24] and the South Saskatchewan Regional Plan (SSRP) has recently been approved. However, the creation of regional plans does not, in and of itself, mean that the environmental goals of $A L S A$ will be delivered. Indeed, the experience gained so far with the LARP suggests that a gap in ambition remains.

In keeping with the aspirations of the Framework and goals of $A L S A$, the vision for the Lower Athabasca Region is one in which "the region's diverse economic opportunities are balanced with social and environmental considerations using a cumulative effects management approach" [24] (p. 23). Perhaps optimistically, the LARP's vision seeks to optimize the economic potential of the region's oil sands resource - currently estimated at 169 billion barrels of recoverable oil sands - and diversify the regional economy while also managing landscapes to maintain ecosystem function and biodiversity and managing air and water to support human and ecosystem needs [24] (p. 23). Underlying this vision is the cumulative effects management approach.

The cumulative effects management approach is operationalized in the LARP through a series of management frameworks which set triggers, intended to provoke a proactive response when exceeded, and limits, designed to set clear system based boundaries that are not to be exceeded [24] (p. 27). To this end, an Air Quality Management Framework for the Lower Athabasca Region [25] and a Surface Water Quality Management Framework for the Lower Athabasca Region [26] have been approved, setting air and surface water quality triggers and limits. A Groundwater Management Framework for the Lower Athabasca Region is also in place, although providing only interim triggers for regional groundwater quality and a process to develop final triggers and limits [24] (p. 27). In addition, the LARP commits to updating an existing Surface Water Quantity Management Framework for the Lower Athabasca River, with stakeholders expecting "that when the water management framework is updated it will include a legally binding Ecological Base Flow (EBF), below which water withdrawals will be prohibited" [27].

To the extent that these management frameworks identify and manage regional cumulative effects, they signal an important shift towards a cumulative effects management approach in the Lower 
Athabasca Region. They thus suggest that the otherwise unconstrained discretion afforded the Executive in $A L S A$ has been exercised in a manner consistent with the Framework.

However, the shift to a cumulative effects management approach in the Lower Athabasca Region is far from complete. This is so for several reasons. First, the existing management frameworks are not comprehensive. For example, the triggers and limits in the Air Quality Management Plan apply only to $\mathrm{NO}_{2}$ and $\mathrm{SO}_{2}$, without reference to other air quality components while those within the Surface Water Quality Management Framework apply to only one water body [24] (p. 51). Additionally, as its name suggests, the Surface Water Quantity Management Framework for the Lower Athabasca River applies only to the Athabasca River, with triggers and limits presently monitored and evaluated at only one monitoring station. Second, management frameworks to which the LARP commits, such as a new Biodiversity Management Framework which set targets for selected biodiversity indicators and addresses caribou habitat needs [24] (p. 28), have not yet been developed. Finally, there is no commitment to develop management frameworks for the greenhouse gas emissions associated with the oil sands activity in the Lower Athabasca Region. There is similarly no commitment to develop a Traditional Land Use Management Framework, directed at protecting First Nations' treaty rights and traditional land uses from the cumulative impacts of oil sands development. The significance of this omission was noted in a recent Joint Review Panel Report on the proposed Jackpine Mine Expansion (the "Jackpine JRP Report"), an oil sands operation within the Lower Athabasca Region [28].

Meanwhile, decision-making and development approvals continue within the Lower Athabasca Region despite the presence of these gaps. This necessarily compels decision-making in relation to these environmental impacts on a project-by-project rather than a cumulative effects management basis [28] (paragraph 36). Decision-makers cannot wait until these management frameworks are in place. The LARP itself makes it clear that decision-makers "must not adjourn, defer, deny, refuse or reject any application, proceeding or decision making process before it" by reason only of non-compliance with a provision or incompletion of any direction or commitment in either the LARP Strategic Plan or the LARP Implementation Plan" [24] (section 7(3)). Given this, the Jackpine JRP recognized that it was "critical that the frameworks, plans, and thresholds identified in the LARP be put in place as quickly as possible" [28] (paragraph 14), and thus encouraged the government of Alberta "to continue the processes associated with implementation of the LARP on anurgent basis" [28] (paragraph 32).

However, unlike $S A R A$ as discussed below, beyond encouraging the executive to fully implement the LARP, there is no means to compel the completion of management frameworks even when the LARP itself contemplates their creation within specified timelines. Rather, until approved, these management frameworks are referred to in sections of the LARP which are "not intended to have binding effect", serving instead as statements of government policy to guide government, decision-makers and local government bodies [24] (Sections 4 and 5). In other words, there is no role for the courts to require the executive to fill these gaps. Until this happens the LARP as currently implemented cannot be said to be more than an "essential first step" [28] (paragraph 1806) in the shift to a cumulative impacts management approach in the Lower Athabasca Region.

Even then, the LARP leaves it to Ministerial discretion to ultimately determine the length of this first step. At present, the air quality and surface water quality management frameworks for the Lower Athabasca region each specify air quality and surface water quality limits - which according to the LARP are designed to set clear system based boundaries that are not to be exceeded. However, when 
one or more of the limits is exceeded, the LARP leaves it to the Minister to issue a notice that, amongst other things, specifies the "action to be taken by the affected decision-makers [...] in response to the exceedance of the limit" [24] (Sections 25(1)(g),(h) and 32(1)(g),(h)). It remains to be seen how the Minister will exercise this discretion in the face of an exceedance. However, the Jackpine JRP Report envisages that this may happen sooner rather than later, with modeling from the Mine's proponent predicting that LARP limits for both $\mathrm{NO}_{2}$ and $\mathrm{SO}_{2}$ will be exceeded in the regional study area where the mine expansion is planned [28] (paragraphs 275-276). The Panel was also "of the view that many oil sands facilities have been approved but not yet built and that model predictions serve as a warning that the (Alberta Ambient Air Quality Objectives) and LARP limits may be exceeded when all approved oil sands facilities become operational" [28] (paragraph 277). If this occurs, the Minister will need to decide the action to be taken in the face of the exceedance under a regional plan that contains a vision of both optimizing the economic potential of the oil sands and maintaining healthy ecosystems and the environment through a cumulative impact management approach.

\subsection{Summary}

The $A L S A$ project is a work in progress. Full implementation depends on the continued exercise of Executive discretion in a manner that remains faithful to the Framework's stated goals and the Act's purposes. Until this occurs, it is not possible to conclude that a gap exists between the ambition of this statute and its actual implementation. However, if $A L S A$ does fail to fulfill its environmental promise, the root cause may well be traced back to the decision of the legislature to afford excessive discretion to the executive to implement this progressive legislation, with little room available to the courts to constrain the exercise of this discretion or oversee ALSA's implementation.

\section{The Species at Risk Act}

It has been roughly four decades since scientists first began to appreciate what is now understood as the "sixth major mass extinction event of all geological time." [29] The United States was one of the first countries to take this threat seriously, passing its Endangered Species Act [30] in the early 1970s as part of that country's environmental decade. Two decades later, Canada committed to develop legislation for the protection of threatened species as the first signatory to the United Nations Convention on Biological Diversity (1992) [31]. It took another decade for Parliament to pass SARA.

If $A L S A$ is an example of what environmental law should be (proactive, preventative, and ecosystem-based), then $S A R A$ and its various counterparts have the dubious (if to some extent unavoidable) distinction of being inherently reactive, a sort of "emergency room" for species facing the threat of extinction. SARA's stated purpose is "to prevent wildlife species from being extirpated or becoming extinct, to provide for the recovery of wildlife species that are extirpated, endangered or threatened... and to manage species of special concern to prevent them from becoming endangered or threatened" [17] (Section 6). Thus, although peppered with preventative language, SARA's protective regime is really only engaged when a species is in trouble, which, as a general rule, is something that good environmental laws should avoid or at least minimize.

However, as further discussed below, when SARA's protective regime is engaged, the legislation makes up for its reactive nature by imposing numerous mandatory duties on relevant government 
departments to ensure that species are given the best possible chance at recovery. In this way, $S A R A$ appears to be following the footsteps of its older American cousin, described as the "pit bull" of that country's environmental law regime [32].

\subsection{Brief Overview of the Legislative Scheme [33]}

As with all such legislation, a species must be legally listed to receive protection under the Act. Under $S A R A$, this is a two-stage process with the Committee on the Status of Endangered Wildlife in Canada (COSEWIC) recommending species for listing but the ultimate decision lying with the Governor in Council (Cabinet) [17] (Section 27). When a species is listed as either endangered, threatened or extirpated, two basic prohibitions apply. The first is a prohibition against harming, collecting or trading in that species [17] (Section 32); the second is a prohibition against destroying its "residence" [17] (Section 33). For reasons not relevant here but of considerable practical importance [34], these prohibitions only apply on federal lands, to aquatic species and to migratory birds under the Migratory Birds Convention Act, 1994 [35].

Listing also triggers a two-stage recovery process. The first stage involves the preparation of a "recovery strategy," a draft of which must be completed within set time frames. The recovery strategy must include a description of any identified "critical habitat": "the habitat that is necessary for the survival or recovery of a listed wildlife species..." [17] (Section 2). In the second stage, an "action plan" is developed, outlining the specific measures to be taken to implement the recovery strategy and including the identification of any additional critical habitat.

Identification of critical habitat is a prerequisite to its protection, which under $S A R A$ is achieved through two principal mechanisms. The first and arguably preferred mechanism (by the current federal government at least) [36] is stewardship activities through conservation agreements [17] (Section 11); the second is the prohibition against destruction of critical habitat [17] (Section 58). As with the prohibitions mentioned above, the critical habitat prohibition is limited to federal lands, aquatic species, the exclusive economic zone and continental shelf of Canada, and to migratory birds under the $M B C A, 1994$.

Finally, and as a partial response to the federal limits referred to in the previous paragraphs, $S A R A$ contains "safety net" provisions authorizing federal protection of a species and/or its critical habitat that otherwise falls squarely under provincial jurisdiction [17] (Sections 34,61,80).

We consider the implementation of each of these elements - listing, the recovery process, and the safety-net - in further detail below. Each demonstrates the positive effects of limited or constrained discretion in achieving SARA's goals. The latter two elements also illustrate the positive role that the law, here in the form of the courts, can play in assisting environmental laws to fulfill their promise.

\subsection{SARA as Constrained Discretion Legislation}

\subsubsection{The Listing Process}

As noted above, COSEWIC plays a fundamental but not exclusive role in species listing. Pursuant to Section 27, COSEWIC makes a recommendation to Cabinet which then has nine months to decide between three options. It can accept the recommendation and list the species; it can decline the recommendation, but in such a case must provide reasons for the decision; or it can return the issue to 
COSEWIC for further clarification [17] (Section 27) [37]. This approach, which has been described as an example of "constrained discretion," was actually the result of a last minute political compromise that ensured SARA's passage [38]. Proponents "believed it would lead to a higher rate of species listing than the purely discretionary approach - that the timing and transparency requirements would induce cabinet to list more species than it otherwise would" [38]. The other approaches to listing adopted in other jurisdictions are scientific listing (i.e., no discretion), and full discretion.

The mere existence of this "constrained discretion" approach is worth noting. It demonstrates that unbounded discretion is not an immutable characteristic of Canadian environmental law. Elgie has tested the claim that different approaches affect the rate of listing. Setting aside the scientific listing jurisdictions, the results showed "a substantial difference in listing rates between jurisdictions with 'Full Discretion' (35\%) and those with 'Constrained Discretion' (78\%)" [38] (p. 14), supporting the general thesis that constraining discretion will lead to faster listing.

\subsubsection{Recovery Strategies}

The basic elements of the recovery strategy process were recently set out in detail by Bankes [39]. Briefly, section 37 requires a "competent minister" to prepare a recovery strategy for an endangered or threatened species. Section 41 sets out the requisite elements of a recovery strategy, including the "identification of the species' critical habitat, to the extent possible, based on the best available information". Pursuant to Section 42, proposed recovery strategies for species listed as endangered when the 'List of Wildlife Species at Risk' came into force (23 June 2003) were required within three years, whereas for threatened species it was four years. For all subsequently listed species, proposed recovery strategies are to be posted within one year for endangered species and two years for those that are threatened. Finally, pursuant to Section 58 and with respect to species not found in national parks, a competent minister has 180 days after a recovery strategy or action plan is posted to either confirm and explain through a "protection statement" that any identified critical habitat is legally protected or issue a "protection order" to achieve this effect.

Each of these requirements has been contested by the federal government, resulting in delays and eventually litigation by various environmental organizations [40]. In each case, the courts rules against the federal government and have interpreted the relevant provisions as non-discretionary.

\subsubsection{Identification of Critical Habitat}

SARA's "critical habitat" provisions have been considered in three cases but only the first, Alberta Wilderness Assn v Canada (Minister of the Environment) [Greater Sage Grouse] [41], is directly relevant here. In that case, the applicants sought judicial review of the recovery strategy for the Greater sage grouse on the basis that it failed to identify any "critical habitat" even though the existence of such habitat was widely known. Foreshadowing future SARA litigation, the respondent Minister did not actually dispute the non-discretionary nature of the critical habitat provisions but rather attempted - unsuccessfully - to shield this failure from review by framing it as a question of fact requiring curial deference [41] (paragraphs 45-57). Consequently, the interpretation endorsed by the Court required the Minister to "identify in a recovery strategy document as much critical habitat as it is 
possible to identify at that time, even if all of it cannot be identified, and to do so based on the best information then available" [41] (paragraph 25).

In other words, the Minister has a "duty to identify critical habitat for the species as part of preparing a recovery strategy and an action plan" [39] (p. 40). The Court noted that such a requirement "reflects the precautionary principle that "where there are threats of serious or irreversible damage, lack of full scientific certainty should not be used as a reason for postponing measures to prevent environmental degradation" " [41] (paragraph 25), citing the Supreme Court of Canada in its landmark decision Spraytech v. Hudson (Town) [42]. While the Minister did not argue for any discretion, the record before the Court did include a draft policy document that strongly hinted at an interpretation whereby the Minister would have some discretion to identify critical habitat at either the recovery strategy stage or at the action plan stage [41] (paragraph 41). This policy and the Court's comments on it are worth noting because they illustrate the potential harm to species that would result if indeed the identification of critical habitat were discretionary [41] (paragraph 42):

This draft policy does imply...discretion whether to identify critical habitat in a recovery strategy or in an action plan and it leans strongly to the identification in the action plan, rather than in the recovery strategy. As the applicants point out, this leaves endangered species at risk as there is no timeline set out in the $S A R A$ for posting an action plan, whereas there is a short time frame set out in Section 42 of the SARA for the posting of a recovery strategy.

As environmental groups were just learning, however, the federal government was also flagrantly ignoring the legislated times frames set out in Section 42, as the next section sets out.

\subsubsection{Timeframes}

Section 42's timeframes were the subject of the most recent SARA litigation. In Western Canada Wilderness Committee v. Canada (Fisheries and Oceans) [White Sturgeon] [43], the applicants sought declaratory relief and mandamus with respect to the long overdue recovery strategies for four distinct species: the White Sturgeon (Nechako River population), the Humpback Whale (North Pacific population), the Marbled Murrelet and the Woodland Caribou (Southern Mountain population).

As in Greater Sage Grouse, the respondent Ministers (Fisheries and Oceans Canada and Environment Canada) acknowledged that "SARA does not confer any discretion on the Ministers" to extend the time for the preparation of recovery strategies, that the Ministers were "legally required to comply with the statutory timelines and they have not done so," and that these breaches "were not minor: there were "substantial delays" [43] (paragraph 41). Also as in Greater Sage Grouse, the Ministers' unsuccessful defense was primarily rooted in principles of administrative law [43] (paragraphs 115-122). Although the Court declined to grant mandamus for reasons of mootness (with respect to the proposed recovery strategies that had recently been released, a point to which we return below) [43] (paragraphs 114-115) and prematurity (with respect to the final recovery strategies) [43] (paragraphs 123-124), it did grant the declaratory relief sought, i.e., that the Ministers had "acted unlawfully in failing to post proposed recovery strategies...within the statutory timelines prescribed in the [SARA]" [43]. 
As in Greater sage grouse, the Court demonstrated a clear understanding of the rationale behind the mandatory timelines, echoing the aforementioned "emergency room" nature of the legislation [43] (paragraphs 102):

To state the obvious, [SARA] was enacted because some wildlife species in Canada are at risk. As the applicants note, many are in a race against the clock as increased pressure is put on their critical habitat, and their ultimate survival may be at stake... Compliance with the statutory timelines is critical to the proper implementation of the Parliamentary scheme for the protection of species at risk.

\subsubsection{Protection Statements $v$. Protection Orders}

Once critical habitat has been identified, whether in a recovery strategy or action plan, Section 58 requires a competent minister to either issue a protection statement or make a protection order. The former is essentially a statement by the competent Minister explaining how the identified critical habitat is already "legally protected" under existing rules, while the latter is effectively a new regulation providing such protection where there is none or there are gaps in the existing protection. The choice between these two was one of the main issues raised in Georgia Strait Alliance v Canada (Minister of Fisheries and Oceans) [Killer Whale] [44].

Unlike Greater Sage Grouse and White Sturgeon, in Killer Whale the Minister did argue for discretion: "Parliament intended to afford some flexibility for the manner in which critical habitat protection is provided. Any protection statement...does not have to rely upon statutory provisions and instruments which provide protection 'in the same manner as the protection order'" [44] (paragraph 260). As in Greater Sage Grouse and White Sturgeon, however, the Court held that the relevant provisions were non-discretionary [44] (paragraph 272) (an interpretation subsequently upheld by the Federal Court of Appeal [45]):

When read in context, subsection 58(5) mandates the minister to ensure that critical habitat is "legally protected." The minister is obliged to make a protection order under subsection 58(5)(a) "if the critical habitat or any portion of the critical habitat is not legally protected..." I do not think that subsection 58(5)(a) should, or can, be read so as to provide the Minister with an "option" to forgo making a protection order under subsection $58(5)(a)$ unless the alternative sources of protection are of the same kind, degree and scope as the protection afforded by subsection $58(5)(a) \ldots$

In other words, the Minister has a "duty to provide for the legal protection of identified critical habitat" [39] (p. 40). In addition and to an even greater extent than Greater Sage grouse, the Court considered the weaknesses and dangers inherent to a discretionary approach [44] (paragraph 279):

This [discretionary] approach is problematic in two ways. First, it conflicts with a plain and ordinary reading of SARA in context. Second, it is contrary to Parliament's expressed intent that the basic protections of $S A R A$ (to which there are exceptions) should be mandatory and should not rest with the discretion of particular ministers. These ministers, no doubt, will face enormous pressures from time to time to back away from or modify those mandatory prohibitions for purposes of political or economic expedience. As the 
Parliamentary debates show, however, this is the very reason why Parliament opted for mandatory prohibition over ministerial discretion...

Thus, the Federal Court recognized what the Canadian Bar Association (in its submissions before Parliament) [46] and numerous scholars have long argued that discretionary decision-making is "subject to the political, economic, and social winds of the time and place in which any particular decision occurs" and that "such winds usually favour business as usual," not environmental protection [47].

\subsubsection{The Safety-Net}

Pursuant to Section 80, if a competent Minister is of the opinion that a species faces "an imminent threat to its survival or recovery," he or she must recommend that the Governor in Council (i.e., the federal Cabinet) make an "emergency order to provide for the protection of a listed wildlife species" (an EPO). The federal cabinet is not obligated to follow the recommendation, but if it does the EPO is not restricted to federal lands in the same way that $S A R A$ 's other provisions are. The safety net provisions have twice been considered by the courts. In Adam v. Canada (Environment) [Boreal Caribou] [48], the applicants had attempted to persuade the Minister of the Environment to recommend an EPO for boreal caribou. The Minister ultimately declined to do so after concluding that "there are no imminent threats to the national survival or recovery of boreal caribou in Canada," a conclusion that the applicants challenged as unreasonable [48] (paragraph 3). The second case, Alberta Wilderness Association v Canada (Attorney General) [Greater Sage Grouse II] [49], is actually the most recent decision in what can be described as the Greater sage-grouse saga, a saga in which that species has continued to decline notwithstanding the earlier court victory and for which therefore the applicants also sought an EPO.

Viewed together, this litigation suggests that the safety net provisions operate somewhat like the listing process, which is to say as a constrained discretion scheme. As with COSEWIC's recommendation in the listing process, the Minister's recommendation under the safety net provisions is also supposed to be science-based. In Boreal Caribou, it was the Minister's inability to reconcile his conclusion not to recommend in the face of "substantial scientific and other evidence" to the contrary that rendered his decision unreasonable [48] (paragraphs 66-68). That being said, all parties were agreed from the outset that "even if the Minister had made a recommendation...the Governor in Council may have declined to issue the requested EPO, after weighing and balancing relevant public-interest considerations" [48] (paragraph 4).

On this latter front, Greater Sage Grouse II provides additional, if somewhat indirect, support for the idea that transparency requirements (here the Minister's recommendation) may induce governments to take more protective decisions than they otherwise would. This support is indirect because it can only be inferred, but there are at least two grounds for doing so. The first is the government's strenuous efforts to keep the contents of that recommendation secret [49] (paragraph 43-50); the second is the fact that, shortly after the Federal Court of Appeal's ruling that such efforts were unlawful, Cabinet did in fact issue an EPO for the Greater sage grouse, the first such order under $S A R A$ [50]. 


\subsection{Summary}

While $A L S A$ demonstrates the capacity for legislative regimes to tackle complex problems like the management of cumulative effects, $S A R A$ demonstrates that legislatures are perfectly capable of limiting or structuring discretion in ways that promote positive environmental outcomes; they can even incorporate the sometimes-maligned precautionary principle [51] in a way that gives it "some work to do" [52]. Yet, SARA is not a story of timely and successful implementation. In his 2013 Fall Report to Parliament, the federal Commissioner for the Environment and Sustainable Development (CESD) noted, inter alia, that "Environment Canada continues to have a significant number of outstanding recovery strategies... 84 percent were overdue by more than three years as of 31 March 2013. Of the recovery strategies that the organizations completed, 43 percent did not identify the critical habitat of the species at risk" [36].

In our view, $S A R A$ 's relatively poor track record can at least partially be explained through the adage "old habits die hard." As the Killer Whale court noted, Canadian politicians and bureaucracies have long been steeped in a culture of discretionary decision-making and do not appear inclined to let go [44] (paragraph 280). This explains why discretionary laws such as $A L S A$ are still so pervasive but it also explains why, in those rare instances where a less discretionary law such as $S A R A$ is passed, there may still be problems in implementation. The important difference between these two statutes, of course, is that the latter example $(S A R A)$ entails unlawful conduct, a point picked up by the courts in most of the SARA litigation. Nooksack Dace (one of the other critical habitat cases not discussed here) [53] was described by the Court as "a story about the creation and application of policy by the Minister in clear contravention of the law, and a reluctance to be held accountable for failure to follow the law" [53] (paragraph 2) while the Court in White Sturgeon felt compelled to remind the Ministers that "public officials are not above the law" [43] (paragraph 66). Finally, in what can only be considered a rebuke of the government's efforts to conceal the status of the Minister's recommendation in Greater Sage Grouse II, the Court invoked what is perhaps still the most important Canadian decision on the rule of law-Roncarelli v Duplessis [54], wherein the relevant Minister (Duplessis) had revoked a restaurant owner's liquor license on the unlawful basis that the latter was using his profits to bail Jehovah's Witnesses out of jail.

In addition to explaining $S A R A$ 's poor record "on the ground," the government's refusal to comply with $S A R A$ 's relatively strict provisions also highlights the positive role that can be played by the courts "to see that important legislative purposes... are not lost or misdirected in the vast hallways of the federal bureaucracy" [19]. Indeed, there would probably still be no critical habitat identified or EPO issued for the Greater sage grouse, no proposed recovery strategies for the White Sturgeon and Marbled Murrelet, and no legal protection for the Killer Whale's critical habitat absent litigation and the courts' insistence on adherence to the rule of law [43] (paragraph 133).

That being said, resort to litigation is by no means an optimal solution. Litigation is costly, labor intensive and time consuming, the latter being especially problematic in the SARA context as evidenced in the Greater Sage Grouse II litigation. There, in an effort to save time, the applicants sought both mandamus to force the Minister to make a decision regarding a Section 80 recommendation and, in the alternative, judicial review of his decision if he had already decided against such a recommendation. Justice Pelletier expressed some sympathy for the applicants' plight, 
but ultimately concluded that such pleadings were not helpful [49] (paragraph 36): “This well-intentioned but ill-conceived effort to save time has resulted in this application being stalled for more than a year on a procedural point of document production which does not begin to address the merits of the appellants' legitimate preoccupation with the survival of the remaining Canadian stocks of Sage-grouse."

In light of these challenges, several jurisdictions have experimented with specialized environmental tribunals. We consider the experience with one such tribunal-Alberta's Environmental Appeals Board-in the next part of this paper.

\section{The Environmental Appeals Board of Alberta}

The Environmental Appeals Board of Alberta (EAB) [55] was established in 1993 with the entry into force of the Environmental Protection and Enhancement Act (EPEA) [18], Alberta's omnibus environmental legislation which deals with such diverse matters as air and water pollution and environmental assessment. The EAB can consider appeals of government decisions under a number of statutes including EPEA and the Water Act [56]. These include decisions in relation to water licenses, reclamation certificates and environmental protection orders. The historical record suggests that both industry and civil society favoured the introduction of an appeal regime. Industry wanted an appeal mechanism because of concerns as to the lack of consistency in the permitting process. Civil society favoured an appeal mechanism as a way of providing an additional opportunity for public input into government permitting and licensing procedures [57].

An EAB may also serve the function of "shining a light" on the administrative procedures of those line departments of government responsible for licensing new projects and developments [57]. Government bureaucracies have a tendency to follow past practices and to be insufficiently inattentive to the principles and purposes articulated in modern environmental statutes. An EAB process provides one way of examining departmental decision-making in light of such principles and purposes. For example, the reasoned decision of an EAB may examine and articulate the relationship between a particular licensing power and the precautionary principle or the polluter pays principle [58].

An expert appeal mechanism is far more likely than a judicial review application to achieve such a result for two related reasons. First, expert appeal procedures are generally structured as de novo appeals in which the parties may present new evidence. Such an appeal is not simply a review of the existing record. A second and related point is that the appeal body does not owe a duty of deference to the original statutory decision maker. In more technical terms, the standard of review is more likely to be correctness rather than reasonableness. By contrast, judicial review procedures are typically structured as reviews on the basis of the existing record and characterized by a high degree of deference to the statutory decision-maker. The review is more likely to be on the basis of reasonableness rather than correctness [59]. Hence, if the statutory decision-maker's decision falls within the range of possible responses a reviewing court will not interfere. Furthermore, a reviewing court never gets to act as the substitute decision-maker or to draft new terms and conditions under which a project might have been approved. The most the reviewing court can do is to send the matter back to the original decision maker with directions to correct the error of jurisdiction or law that has been identified. 
However, the ability of a body like the EAB to "shine a light" on the administrative practices within the line departments responsible for licensing and permitting decisions for an array of resource development projects depends upon two related things: the scope of the provisions that trigger the review jurisdiction of the Board, and the scope of the standing provisions that allow a party to take a case to the Board. The trigger provisions are not the focus of this paper although we will see that the two issues are interrelated and cannot be completely separated. In general, the trigger provisions of the legislation afford the Board jurisdiction over a broad range of decisions except appeals from planning level decisions [18,56,57]. More recently, the creation of a "single window" energy regulator in the province with the authority to make licensing and permitting decisions (that historically would have been made by line departments) where those decisions relate to energy projects, has further limited the availability of appeals [60].

The focus of this part of the paper is the second possible limitation on the jurisdiction of a board like the $\mathrm{EAB}$, the relevant standing rules. Where a project has a direct effect on private interests there is typically little difficulty in acquiring standing to appeal a statutory decision to a board like the EAB, or judicial review in front of a court. However, where a project affects public interests (and all projects must do so to some degree insofar as they have the potential to impair public values and resources including ecosystem values, air and water quality, and public resources such as the capacity of the atmosphere to absorb greenhouse gases without interfering with the climate system) it may be much more difficult for a party claiming to represent that interest to acquire standing. This is significant since it is public interests and values that typically go uncompensated in resource development projects. Discrete private interests are far more likely to be engaged and compensated by project proponents than are public interests. These interests may go unaddressed for want of an advocate or will simply be factored in to some general Kaldor/Hicks cost benefit analysis.

This part of the paper draws attention to the fact that the EAB in Alberta, in common with other regulatory bodies in the province [61], has labored under restrictive statutory standing rules which have limited the Board's authority to "shine a light" on the permitting and licensing practices of line departments. Furthermore, the Board itself has been timid in the application of the standing rules and the courts in reviewing Board decisions have certainly not encouraged it to be more imaginative. This stands in stark contrast to the general jurisprudence on standing in the ordinary courts. Here, we see the courts articulating a broad view of the concept of public interest standing in order to reinforce important and fundamental values such as accountability and the rule of law. The contrast between the narrow statutory standing jurisprudence for tribunals like the EAB and the more liberal jurisprudence of the general courts is unhelpful given the role that we want boards like the EAB to play in protecting public interests.

The balance of this part of the paper proceeds as follows. The next section summarizes the law of the general courts on public interest standing. This is followed by a description of the standing rules of the $\mathrm{EAB}$ as well as the practice of the Board and the jurisprudence of the Courts in reviewing the Board's practice. The discussion concludes by suggesting how we might move forward. 


\subsection{The Law of the General Courts on Public Interest Standing}

Canadian Courts first started to articulate a liberal view of public interest standing in a series of constitutional cases beginning in the mid-1970s [62,63]. The Supreme Court of Canada extended this to mainstream administrative law in the mid-1980s [64]. The Court liberalized the rules still further in its recent decision in Canada (Attorney General) v Downtown Eastside Sex Workers United Against Violence [65]. Prior to this most recent decision, the general law on public interest standing with respect to both constitutional and administrative law matters could be summarized as follows. While a party with private interest standing (i.e., a party directly affected by the matter and in way that was distinct from that of other members of society) might have an audience before the Courts as of right, a Court may afford a party standing on a discretionary "public interest" basis where that party can establish three things. First, the party should be able to establish that it was raising a serious justiciable issue. In other words, the application must raise a point of law rather than a question of policy or politics. Second, the party should be able to establish a real stake or a genuine interest in the issue. While the term "real stake" hearkens back to the idea of a private interest, the "genuine interest" concept is clearly more malleable. Public interest interveners typically address this question by referring to the objects and purposes clause of their incorporation or society status and by pointing to a track record of activism in the area. Third, the party must be able to show that the proposed suit is a reasonable and effective way of bringing the issue before the courts. In some cases, this has been expressed more restrictively as requiring the party to show that there is no other reasonable and effective means of bringing the issue to the Court. This last criterion can pose an obstacle for the environmental public interest litigant since, as noted above, a development project will frequently engage private as well as public interests. Thus, in many cases, there will be a private party who has standing as of right to appeal or seek judicial review of a statutory decision. However, such a party may lack the resources or interest to pursue the matter and in any event may only be interested in protecting or raising private interests. That party may also have had its concerns addressed by the proponent. If applied restrictively, therefore, this third criterion may be used to deny an applicant public interest standing.

This was precisely the issue in Downtown Eastside Sex Workers. In that case, the applicant Society sought to question the validity of sections of the Criminal Code. The Attorney General took the position that the Society had no standing to raise the issue since there were other individuals (e.g., individual sex workers) who would clearly have standing as of right. The Supreme Court however ruled that this should not be conclusive of the issue and granted standing. The Court referred to a number of factors in support of that conclusion: including the public importance of the issue transcending immediate private interests; the comprehensive nature of the challenge; the skill and expertise of the applicant; and the court's own assessment that it was unlikely that an individual with standing would raise all of the issues that the applicant sought to question [65] (paragraph 73). More generally, the Court favoured a purposive approach to the assessment of standing. The Court located its approach to standing in the principle of legality which contains two ideas, "that state action should conform to the Constitution and statutory authority and that there must be practical and effective ways to challenge the legality of state action" [65] (paragraph 31). 
In sum, the ordinary Courts have developed relatively liberal rule of standing to accommodate public interest litigation. There is no standing as of right but the Courts retain the discretion to grant standing where they can be convinced that this is a reasonable and effective way of assessing the legality of state action.

\subsection{Standing before the Environmental Appeals Board}

The ordinary Courts develop their standing rules as part of their inherent jurisdiction to control their own procedure. In the case of an appeal board, the standing rules will necessarily be prescribed by statute because the question of who may commence an appeal is an essential part of establishing the jurisdiction of the board. The interpretation of those statutory standing rules falls, first of all, to the board itself.

The statutory standing rules for the Environmental Appeals Board (EAB) provide in general terms that an appeal may be commenced by the person who applied for the relevant statutory approval, permit or licence and by "any person who previously submitted a statement of concern ... and who is directly affected by the ... decision" [18] (Section 91) [56] Section 115(1)). Thus, an environmental organization or other potential public interest intervener must establish both that it filed a statement of concern and that it is directly affected. Such organizations have also pursued another avenue for access to the Board arguing to the effect that the Board still has the jurisdiction to entertain an appeal even where the organization cannot establish that it is directly affected if it can establish that it meets the tests for public interest standing developed by the ordinary courts and discussed above. However, neither approach has proven successful for public interest litigants. The Board has taken a narrow approach to the interpretation and assessment of "directly affected" and rejected outright the suggestion that it has any authority to hear an appeal based upon the public interest standing of an applicant $[57,66]$. The courts have generally declined to interfere with the Board's interpretation and application of the test [67-69].

Both points are clearly established in an EAB decision and subsequent judicial review application in a case involving applications to amend large volume irrigation licences [66]. The statutory decision maker granted the applications and three public interest environmental organizations (the ENGOs) filed appeals arguing that the amendments were unlawful. The EAB put at issue the standing of the ENGOs to initiate the appeal and set that matter down for decision before considering the merits of the appeals. All three ENGOs argued that they were directly affected, or, in the alternative, that they should be granted public interest standing with the necessary implication that this was sufficient to accord the Board the jurisdiction to consider the appeals. In support of their claim to standing on both grounds, the ENGOs all provided evidence of their long-standing commitment to some or all of the following issues: watershed and conservation planning, water allocation and transfer matters, and instream flow and healthy aquatic ecosystems. The ENGOs also emphasized that the interpretation of the term "directly affected" should be informed by the statement of purposes in the Water Act which include the following [56] (Section 2):

The purpose of this Act is to support and promote the conservation and management of water, including the wise allocation and use of water, while recognizing: 
(a) the need to manage and conserve water resources to sustain our environment and to ensure a healthy environment and high quality of life in the present and the future;

(d) the shared responsibility of all Alberta citizens for the conservation and wise use of water and their role in providing advice with respect to water management planning and decision-making;

(f) the important role of comprehensive and responsive action in administering this Act.

In considering the directly affected issue, the Board confirmed that "When the Board assesses the directly affected status of an appellant, the Board looks at how the person uses the area where the project will be located, how the project will affect the environment, and how the effect on the environment will affect the person's use of the area. The closer these elements are connected (their proximity), the more likely the person is directly affected. The onus is on the appellant to present a prima facie case that he or she is directly affected" [66] (paragraph 105). By "proximity", what is meant is "how closely tied" the decision is with "the possible effects on a natural resource and the possible effects on the appellant's use of that resource" [66] (paragraph 124). Thus, the test is very much a "land-based" test, or as the Board puts it later in its decision, "The cornerstone of all the cases before the Board is the factual impact of the proposed project on individuals" [66] (paragraph 116). Thus, engagement with the issues identified in the purposes of the Water Act is not sufficient to meet the directly affected test. A "genuine interest" does not suffice [66] (paragraph 119), and neither does engagement in water management and ecosystem protection [66] (paragraph 123) or the assumption of an advisory role [66] (paragraph 126). The Board offered the following additional guidance [66] (paragraph 109):

The effect on the appellant does not have to be unique in kind or magnitude. However, the effect the Board is looking for needs to be more than an effect on the public at large (it must be personal and individual in nature), and the interest which the appellant is asserting as being affected must be something more than the generalized interest that all Albertans have in protecting the environment. Under EPEA and the Water Act, the Legislature chose to restrict the right of appeal to those who are directly affected by the Director's decision. If the Legislature had intended for any member of the public to be allowed to appeal, it could have used the phrase "any person" in describing who has the right to appeal. It did not; it chose to restrict the right of appeal to a more limited class. The Legislature, in using the more restrictive language, also did not intend for the Board to provide a general right of review for the Director's decision; it intended it be something narrower.

The Board also had to grapple with an issue that had been before it on numerous previous occasions, namely the application of such a land-based, directly affected test, to a group, and especially a membership based group like the Alberta Wilderness Association or Trout Unlimited. Here, the Board emphasized that a group could not obtain standing independently of its members. That is to say, in order for the group to obtain standing it would need to show that at least some of its members (and perhaps a majority), would be "individually and personally impacted by the Director's decision"- and in the land or resource-based way discussed above. Since the applicants had not presented evidence of the interest of particular members, they were therefore unable to claim standing based on the "directly affected" test. 
That left the applicants with the claim based on public interest standing. The Board, applying a pre-Downtown Eastside version of the test, was clearly not convinced that the case law on public interest standing in the ordinary courts was of any application here [66] (paragraph 133). While the Board agreed that there was a serious issue to be determined (the legality of the amendments) [66] (paragraph 135), it seems to have concluded that no other elements of the test were satisfied. The issue was not justiciable; the applicants might have had a genuine interest in licence amendments generally but perhaps not with respect to these amendments; and there were reasonable and effective means for the issue to be brought before the Courtslthe Board i.e., a person who was directly affected [66] (paragraph 147). More generally however, and with no additional reasoning, the Board simply concluded that "Granting public interest standing is not within the Board's jurisdiction" [66] (paragraph 141).

It does not appear as if the applicants sought judicial review of the Board's decision under the directly affected test but they did seek judicial review of the public interest standing matter arguing both that the Board had erred in concluding that it had no jurisdiction to grant public interest standing and by wrongly concluding that the applicants had not met the tests. Justice Hall only dealt with the jurisdictional issue and for him the issue was not so much the jurisdiction to grant public interest standing as much as it was the proposition that the Board only had the jurisdiction to hear an appeal from a party that was directly affected. This is quite different from a judicial review setting in the courts in which standing is treated as a procedural matter rather than as a substantive jurisdictional matter. Justice Hall put the point as follows [67] (paragraph 27):

With respect to an appeal of the Director's decisions to amend water licences, the Board only has the jurisdiction that was granted to it by the provisions of the Water Act. The Water Act did not grant the Board the jurisdiction to hear public interest appeals. It can only hear appeals from parties directly affected by the decisions of the Director. The Board receives its jurisdiction from the provisions of the Water Act. It is a legislated jurisdiction. The Board cannot exceed that jurisdiction. The Board has no inherent jurisdiction.

In conclusion, the ability of board like the Environmental Appeals Board to shine a light on the permitting practices of a line Department and take a broad purposive approach to the interpretation of permitting statutes will only be effective if the EAB is able to assume jurisdiction over important cases. Narrow standing rules may seriously inhibit the Board's ability to discharge this important function. The analysis here suggests that the standing rules built into the legislation and the Board's interpretation of those rules have had this effect in the case of Alberta's EAB.

The legislative rules are narrow in two respects. First, the "directly affected" test is a demanding test to meet. It is certainly much more demanding than a genuine interest test. Second, since the "directly affected" language also serves as a trigger to Board jurisdiction, this language serves to ensure that any decision by the Board to grant a party public interest standing will not be enough to afford the Board jurisdiction to consider the matter if it does not already have jurisdiction by some other means. Thus, if a party who is directly affected initiates the appeal, another party who might have been afforded public interest standing will not be able to sustain the application if the directly affected party withdraws its objections.

The Board has more room to move with respect to the interpretation and application of the "directly affected" test than it does with respect to the jurisdictional issue just discussed. As Justice Hall points 
out, the legislature has restricted the categories of persons who can launch an appeal. The Board cannot add an additional category, i.e., persons with a genuine interest - and any attempt to do so would be met by an application for judicial review in which the standard of review would be correctness [68] (paragraph 27). The Board could, however, take a more expansive view of "directly affected" and interpret that term in a less physical way and in a way that is informed by the purposes of the statute. A decision on such a matter is more likely to be reviewed on the basis of reasonableness rather than on the basis of correctness [59].

\subsection{Summary}

An environmental appeal board is an important tool in fostering a purposive interpretation of environmental statutes. An EAB can only serve that enlightened role if it is allowed to assume jurisdiction. Statutorily created triggers to jurisdiction and related standing rules may wittingly or unwittingly limit access to such boards and may do so in a way that is more limiting than the standing rules of the ordinary courts. That seems both anomalous and hard to justify. One would expect that the standing rules of specialized appeal tribunals should be at least as liberal as the ordinary courts for it would be truly anomalous if the result of creating a specialized tribunal was to make it more difficult to have the decisions-making practice of line department subject to review. Accordingly, we suggest that the relevant statutes should be amended to incorporate the concept of public interest standing as an alternative to the current directly affected test.

\section{Conclusions}

This paper has discussed three different environmental statutes in order to assess whether there is a gap between their ambition and their actual implementation. Our review suggests that there are several inter-related factors that may get in the way of effective implementation.

The first and generally well-understood factor is discretion. Statutes may be drafted in mandatory or discretionary terms; and within the area of executive discretion there is a broad spectrum of possibilities. The importance of discretion (and its absence) is well illustrated in our discussion of both ALSA and SARA. The ALSA discussion shows that the highly discretionary nature of that statute makes it exceptionally difficult to assess the extent to which that statute will ultimately achieve its lofty goals. Nobody doubts the ambition behind the policy documents that informed the development of $A L S A$ but there is potentially a large gap between ambition and implementation. Furthermore, because the statute is framed in very discretionary terms, that gap can only be bridged at the political level; failure of the executive to act cannot be questioned in a court of law. Consequently, any failure in $A L S A$ 's implementation will be a failure not of law but of politics.

A different story emerges when we look at $S A R A$. While there is some discretion in the $S A R A$ listing process, it is a constrained form. Furthermore, once a species is listed certain things follow inexorably. In this case the law, in the sense of "rule[s] of conduct or action...enforced by a controlling authority" [70], clearly does have a role to play - and in this case it is a positive one. As the $S A R A$ case law shows, law and core legal ideas such as the rule of law have proven to be instrumental in driving $S A R A$ 's implementation. In these cases, the mandatory language of the statute has allowed ENGOs to use the courts to obtain orders requiring the executive to fulfill its obligations under the 
statute by preparing recovery plans for listed species, identifying critical habitat and making the necessary orders to protect that habitat.

A second and related factor is effective oversight. We have discussed three forms of oversight: political, which is the main form offered by $A L S A$ but which also forms part of SARA's constrained discretion schemes; judicial, which figures most prominently under $S A R A$; and a specialized tribunal, the EAB. Each of these forms of oversight has different strengths and weakness. The experience with $S A R A$ 's listing process and its safety-net provisions (admittedly more tenuously) demonstrates that political oversight, which is to say democratic accountability, clearly has the potential to drive effective implementation, but the extent to which it will actually do so depends also on a complex set of extra-legal factors. A key strength of judicial oversight as exemplified by $S A R A$ is that it is both effective and mandatory, but it is also expensive, time-consuming and piece-meal, a reality illustrated by the increasingly uncertain fate of the Greater Sage Grouse. A key strength offered by the oversight of a specialized tribunal is the possibility of a more searching, purposive and substantive analysis of decision-making at the executive level.

Several lessons emerge. Judicial (and tribunal) oversight is likely to work best when legislation is expressed in mandatory and non-discretionary terms. Such language provides the necessary benchmarks or legal tests against which executive action can be judged and lends itself most to a discussion framed in terms of the rule of law and the proposition that the executive branch can never act outside the law: be you ever so high the law is above you. The same general principle applies where judicial oversight is intended to play only a supporting role to political oversight, as in the case of SARA's safety net provisions. Legislation that is framed in highly discretionary terms, such as $A L S A$, is less amenable to judicial oversight. In some cases, discretionary powers may be not only effectively non-justiciable but may be framed in such a manner that they also cannot be the subject of effective political oversight.

Second, effective oversight, whether by the ordinary courts or by a specialized tribunal, depends upon access and standing. Access to justice requires access to requisite resources (important but beyond the scope of this paper); standing on the other hand is a distinctively legal concept. Although not discussed in any detail in this paper, the $S A R A$ case law makes plain that standing has not been a significant issue for ENGOs seeking to use the ordinary courts to enforce the mandatory obligations of SARA. By contrast, the discussion of Alberta's EAB suggests that standing has been a significant obstacle to the effective use of that body. Finally, in what appears to be a relatively novel variation on the standing question, access to the ordinary courts may be filtered. In $A L S A$, the principal responsibility for ensuring implementation of the regional plans lies with the stewardship commissioner. This is problematic when combined with the highly discretionary powers associated with that office.

Reflecting on the role of law in the success or failures of our three environmental regimes, we observe that law can only contribute to the achievement of the goals of modern environmental statutes to the extent that the legislature and executive permits. In this respect, each of the three environmental law statutes considered here tells a different story. ALSA reveals a story of an eco-system based and cumulative effects management regime, the implementation of which is left largely to the unconstrained discretion of the executive, without the oversight of an independent specialist tribunal or a true role for the courts. Meanwhile, SARA conveys a story of protective legislation, implemented by way of constrained political discretion, with the courts playing a supporting role in overseeing its 
implementation. Finally, the EAB offers a story of a specialist tribunal empowered to foster a purposive interpretation of environmental legislation but hampered in its implementation by statutorily created triggers to jurisdiction and related standing rules which serve to limit access. In each of these stories, the environmental goals are ambitious, but the sub-plots reveal weaknesses that ultimately undermine their effective implementation. For this, the legislature and the executive are responsible - rather than the law itself. Finally, while these environmental statutes could be rewritten to use the legal tools available, until they are, the story from Canada is "mind the (implementation) gap".

\section{Author Contributions}

The authors contributed to all sections of this paper. All authors read and approved the final manuscript.

\section{Conflicts of Interest}

The authors declare no conflict of interest.

\section{References and Notes}

1. Board of the Millennium Ecosystem Assessment. Millennium Ecosystem Assessment, Living Beyond Our Means: Natural Assets and Human Well-Being. Available online: http://maweb.org/ en/Board Statement.asp (accessed on 20 August 2014).

2. Intergovernmental Panel on Climate Change. Summary for Policymakers. In Climate Change 2013: The Physical Science Basis; Stocker, T.F., Qin, D., Plattner, G.-K., Tignor, M., Allen, S.K., Boschung, J., Nauels, A., Xia, Y., Bex, V., Midgley, P.M., Eds.; Cambridge University Press: New York, NY, USA, 2013.

3. Karkkainen, B.C. University of Minnesota Law School, Minneapolis, MN, USA. 2005, unpublished work.

4. Cardozo, B.N. The Nature of the Judicial Process; Yale University Press: New Haven, CT, USA, $1921 ;$ p.178.

5. Emond, D.P. Are We There Yet? Reflections on the Success of the Environmental Law Movement in Ontario. Osgoode Hall Law J. 2008, 46, 229-232.

6. Tarlock, D. Is There a There There in Environmental Law. J. Land Use 2003, 19, 214-254.

7. National Environmental Policy Act, 1970 (42 U.S.C. § 4321) [NEPA].

8. Clean Air Act, 1970 (42 U.S.C. §7401) [CAA].

9. Clean Water Act, 1972, (33 U.S.C. §1251, Title 33) [CWA].

10. Canadian Environmental Protection Act, 1999 (Statutes of Canada 1999 chapter 33) [CEPA].

11. Wood, S.; Tanner, G.; Richardson, B.J. What Ever Happened to Canadian Environmental Law? Ecol. Law Q. 2011, 37, 981-1040.

12. Lazarus, R.J. Environmental Law at the Crossroads: Looking Back 25, Looking Forward 25. Mich. J. Environ. Admin. Law 2013, 25, 267-284.

13. Boyd, D.R. Unnatural Law: Rethinking Canadian Environmental Law and Policy; UBC Press: Vancouver, BC, Canada, 2003; p. 233. 
14. DeMarco, J.D. Building a Strong Foundation for Action: A Review of Twelve Fundamental Principles of Environmental and Resource Management Legislation. J. Environ. Law. Pract. 2008, 19, 67-68.

15. Pardy, B. In Search of the Holy Grail of Environmental Law: A Rule to Solve the Problem. McGill Int. J. Sustain. Dev. Law Pol. 2005, 1, 29-57.

16. Alberta Land Stewardship Act, 2009 (Statutes of Alberta, 2009, Chapter A-26.8) [ALSA].

17. Species at Risk Act, 2002 (Statutes of Canada, 2002, Chapter 29) [SARA].

18. Environmental Protection and Enhancement Act, 1992, (Statues of Alberta, Chapter E-13.3) [EPEA].

19. Calvert Cliffs' Coordinating Committee v. United States Atomic Energy Commission. 449 F.2d 1109, District of Columbia Circuit, 1971 p.1111 (United States Court of Appeal).

20. Bankes, N. ALSA and the property rights debate in Alberta: A certificate of title to land is not a 'statutory consent'. Available online: http://ablawg.ca/2011/02/11/alsa-and-the-propertyrights-debate-in-alberta-a-certificate-of-title-to-land-is-not-a-"statutory-consent (accessed on 20 August 2014).

21. Morton, T. Third Reading, Bill 36, Alberta Land Stewardship Act, 2009.

22. Government of Alberta. Land-use Framework Report. Available online: https://landuse.alberta.ca/ LandUse\%20Documents/Land-use\%20Framework\%20-\%202008-12.pdf (accessed on 20 August 2014).

23. Harvie, A.; Mercier, T.J. The Alberta Land Stewardship Act and Its Impact on Alberta's Oil and Gas Industry. Alberta Law Rev. 2010, 48, 295-330.

24. The Lower Athabasca Regional Plan 2012-2022. Available online: https://landuse.alberta.ca/ LandUse\%20Documents/Lower\%20Athabasca\%20Regional\%20Plan\%202012-2022\%20Approved\% 202012-08.pdf (accessed on 20 August 2014).

25. Government of Alberta. Air Quality Management Framework for the Lower Athabasca Region. Available online: http://environment.alberta.ca/documents/LARP_Framework_AirQuality_ FINAL.pdf (accessed on 20 August 2014).

26. Government of Alberta. Surface Water Quality Management Framework for the Lower Athabasca Region, 2012.

27. Pembina Institute. Solving the Puzzle, 2013. Available online: http://www.pembina.org/pub/2443 (accessed on 20 August 2014).

28. Federal Minister of the Environment and the Energy Resource Conservation Board. Available online: http://www.aer.ca/documents/decisions/2013/2013-ABAER-011.pdf (accessed on 21 August 2014).

29. Wood, P.M.; Flahr, L. Taking Endangered Species Seriously? British Columbia's Species at Risk Policies. Can. Pubulic Pol. 2004, 30, 381-399.

30. Endangered Species Act, 1973 (16 U.S.C. § 1531) [ESA]

31. Convention on Biological Diversity. Int. Legal Mater. 1992, 31, Article 818.

32. Ruhl, J.B. Who Needs Congress? An Agenda for Administrative Reform of the Endangered Species Act. NYU Environ. Law J. 1998, 6, Article 384.

33. A Sierra Legal Defence Fund Report. Available online: http://www.sfu.ca/ amooers/ scientists4species/SARA_Guide_May2003.pdf (accessed on 20 August 2014).

34. Wojciechowski, S. SARA's Safety Net Provisions and the Effectiveness of Species at Risk Protection on Non-Federal Lands. J. Environ. Law Pract. 2011, 22, 204-206. 
35. Migratory Birds Convention Act, 1994 (Statutes of Canada. 1994, Chapter 22) [MBCA].

36. Report of the Commissioner of the Environment and Sustainable Development 2013. Available online: http://www.oag-bvg.gc.ca/internet/English/parl_cesd_201311_05_e_38675.html (accessed on 20 August 2014).

37. Mooers, A.O. Science, Policy, and Species at Risk in Canada. BioScience 2010, 60, 843-849.

38. Elgie, S. Statutory Structure and Species Survival: How constraints on Cabinet discretion affect Endangered Species Listing Outcomes. J. Environ. Law Prac. 2008, 19, 1-32.

39. Bankes, N. Protecting Listed Aquatic Species under the Federal Species at Risk Act: The Implications for Provincial Water Management and Provincial Water Rights. J. Environ. Law Prac. 2012, 24, 40-43.

40. Lemkow, A.; VanderZwaag, D. Recovery Planning under Canada's Species at Risk Act in a Changing Ocean: Gauging the Tides, Charting Future Coordinates. J. Environ. Law Prac. 2014, in press.

41. 2009 FC 710, [Greater Sage Grouse]. Available online: http://www.canlii.org/en/ca/fct/doc/2009/ 2009fc710/2009fc710.html (accessed on 1 September 2014).

42. 2001 SCC 40 (CanLII), [2001] 2 SCR 24. Available online: http://www.canlii.org/en/ca/scc/doc/ 2001/2001scc40/2001scc40.html (accessed on 1 September 2014).

43. 2014 FC 148 (Camlin) [White Sturgeon]. Available online: http:/www.canlii.org/en/ca/fct/doc/ 2014/2014fc148/2014fc148.html (accessed on 1 September 2014).

44. 2010 FC 1233 [Killer Whale]. Available online: http://www.canlii.org/en/ca/fct/doc/2010/ 2010fc1233/2010fc1233.html (accessed on 1 September 2014).

45. Canada (Fisheries and Oceans) v. David Suzuki Foundation 2012 FCA 40. Available online: http://www.canlii.org/en/ca/fca/doc/2012/2012fca40/2012fca40.html (accessed on 1 September 2014).

46. Canadian Bar Association. Bill C-65 Canada Endangered Species Protection Act; Canadian Bar Association: Ottawa, ON, Canada, 1996.

47. Pardy, B. Ecosystem Management in Question: A Reply to Ruhl. Pace Environ Law Rev. 2005, 23, 209-217.

48. 2011 FC 962 [Boreal Caribou]. Available online: http://www.canlii.org/en/ca/fct/doc/2011/ 2011fc962/2011fc962.html (accessed on 1 September 2014).

49. 2013 FCA 190 [Greater Sage Grouse II]. Available online: http://www.canlii.org/en/ca/fca/doc/ 2013/2013fca190/2013fca190.html (accessed on 1 September 2014).

50. Government of Canada. Emergency Order for the Protection of the Greater Sage-Grouse. Available online: http://canadagazette.gc.ca/rp-pr/p2/2013/2013-12-04/html/sup-eng.php (accessed on 21 August 2014).

51. Sunstein, C. Laws of Fear; Cambridge University Press: Cambridge, UK, 2005.

52. Tollefson, C.; Thornback, J. Litigating the Precautionary Principle in Domestic Courts. J. Environ. Law Prac. 2009, 19, 33-58.

53. Alberta Wilderness Assn. v. Canada (Minister of Environment) 2009 FC 710 [Nooksack Dace] Available online: http://www.canlii.org/en/ca/fct/doc/2009/2009fc710/2009fc710.html (accessed on 1 September 2014).

54. Roncarelli v. Duplessis, [1959] SCR 121. Available online: http://www.canlii.org/ $\mathrm{en} / \mathrm{ca} / \mathrm{scc} / \mathrm{doc} / 1959 / 1959 \mathrm{canlii50/1959canlii50.html} \mathrm{(accessed} \mathrm{on} 1$ September 2014). 
55. Environmental Appeal Board home page. Available online: http://www.eab.gov.ab.ca/ (accessed on 20 August 2014).

56. Water Act, 2000 (Revised Statues of Alberta, 2000, chapter W-3).

57. Bankes, N. Shining a Light on the Management of Water Resources: The Role of an Environmental Appeal Board. J. Environ. Law Prac. 2006, 16, 131-185.

58. Alberta Environmental Appeals Board, Report and Recommendations. Available online: http://www.eab.gov.ab.ca/dec/03-116_118-121-R.pdf (accessed on 1 September 2014).

59. Dunsmuir v New Brunswick, 2008 SCC 9. Available online: http://www.canlii.org/en/ca/scc/ doc/2008/2008scc9/2008scc9.html (accessed on 1 September 2014).

60. Bankes, N. Bill 2 and its implications for the jurisdiction of the Environmental Appeal Board. Ablawg, 2011. Available online: http://ablawg.ca/wpcontent/uploads/2012/11/Blog_NB_Bill2_ Jurisdiction_EAB_Nov2012.pdf) (accessed on 21 August 2014).

61. Fluker, S. Public Participation at the Alberta Energy Resources Conservation Board. Resources 2011, 111, 1-6.

62. Thorson v Attorney General, [1975] 1 SCR 138. Available online: http://www.canlii.org/ en/ca/scc/doc/1974/1974canlii6/1974canlii6.html (accessed on 1 September 2014).

63. Nova Scotia Board of Censors v. McNeil, [1976] 2 SCR 265. Available online: http://www.canlii.org/en/ca/scc/doc/1975/1975canlii14/1975canlii14.html (accessed on 1 September 2014).

64. Finlay v Canada (Minister of Finance), [1986] 2 SCR 607. Available online: http://www.canlii.org/ en/ca/scc/doc/1986/1986canlii6/1986canlii6.html (accessed on 1 September 2014).

65. Canada (Attorney General) v. Downtown Eastside Sex Workers United Against Violence Society, 2012 SCC 45, [2012] 2 SCR 524. Available online: http://www.canlii.org/en/ca/scc/doc/2012/ 2012scc45/2012scc45.html (accessed on 1 September 2014).

66. Alberta Environmental Appeals Board, Decision. Available online: http://www.eab.gov.ab.ca/dec/ 10-053-055-11-009-014-D.pdf (accessed on 1 September 2014).

67. Alberta Wilderness Association v Alberta Environmental Appeal Board, 2013 ABQB 44. Available online: http://www.canlii.org/en/ab/abqb/doc/2013/2013abqb44/2013abqb44.html (accessed on 1 September 2014).

68. Westridge Utilities Inc. v. Alberta (Director of Environment, Southern Region), 2012 ABQB 681. Available online: http:/www.canlii.org/en/ab/abqb/doc/2012/2012abqb681/2012abqb681.html (accessed on 1 September 2014).

69. Court of Queen's Bench of Alberta. Available online: http:/www.albertacourts.ab.ca/ jdb_new/public/qb/2003-NewTemplate/qb/Civil/2003/2003abqb0912.pdf (accessed on 1 September 2014).

70. Law Merriam-Webster Dictionary Online. Available online: http://www.merriam-webster.com/ dictionary/law (accessed on 20 August 2014).

(C) 2014 by the authors; licensee MDPI, Basel, Switzerland. This article is an open access article distributed under the terms and conditions of the Creative Commons Attribution license (http://creativecommons.org/licenses/by/3.0/). 